\title{
Flood Risks Factors and their Prevalence in Some Selected Local Government Areas of Jigawa State, Nigeria
}

\author{
${ }^{1}$ Zakaria Aliyu, ${ }^{2}$ Umar Nura Khalil, \\ ${ }^{3}$ Mohammad Laraba Ahmed and ${ }^{4}$ Yusuf, R.O \\ ${ }^{* 1}$ and ${ }^{3}$ Centre for Disaster Risk and Developmental Studies \\ Ahmadu Bello University \\ Zaria \\ ${ }^{2}$ Department of Geography, \\ University of Maiduguri, \\ Borno Nigeria \\ ${ }^{4}$ Department of Geography and Environmental Management, \\ Ahmadu Bello University \\ Zaria \\ Email: aliyuzakaria86@gmail.com
}

\begin{abstract}
Flood in Auyo and Miga local government areas is worrisome. The location of large parts of the study area is lying on the northern bank of Hadejia River, and many communities are at risk of flood hazard. This study is aimed at assessing flood risk factors in the vulnerable communities of Auyo and Miga LGAs, Jigawa State of Nigeria. A sample size of 666 respondents were drawn for selfadministered questionnaire, 601 were fully completed. Data collected were analyzed descriptively for Relative importance index (RII). Findings revealed that, the current trend in the frequency of flood was on the increase, and the year 2012 (59\%) and 2018 (61\%) marked the worst with floods occurring four times. The major causes of flood were heavy rains (with RII of 4.890), overflow of river/stream with RII of 4.866, rainstorm, (with RII of 4.890), long period of rainfall (with RII of 4.805), steep side channels (4.785 of RII) and mystical beliefs (RII of 3.86). Man-made major factors were discovered to include; deforestation (with RII of 4.389) and lack of flood embankment, (RII of 4.316). Others were: poor waste disposal (RII of 3.915), lack of drainage network (with RII of 3.840), and development and infrastructure in flood-prone areas with RII of 3.733. It is recommended that, proper embankment protection and water regulatory outlets should be made available. Delineate flood risk zones before carrying out construction activities, or rather impose resettlement outside the flood prone areas.
\end{abstract}

Keywords: Flood, Factors, Prevalence, High Rainfall, Flood Embankments, Food Mitigation, Drainage network

\section{INTRODUCTION}

As a result of global warming, the climate in Africa is predicted to become more variable, and extreme weather events are expected to be more frequent and severe even with relatively small average temperature increase, with increasing risk to health and life (Few et 
al., 2004). Flood hazard poses one of the greatest natural risks (Ayinde et al., 2013). Floods depend on precipitation intensity, volume, timing, phase (rain or snow), antecedent conditions of river and their drainage basins (e.g. presence of snow and ice, soil character and status frozen or not, saturated or unsaturated), wetness, rate and timing of snow/ice melt, urbanization, existence of dykes, dams and reservoirs). So, variety of climatic processes influence flood, resulting in river, flash, urban, sewer, glacial lake outburst and coastal floods (Few et al., 2004). But very often flood is induced by man's improper utilization or abuse of the environment (UNISDR, 2015). In Nigeria, flood is a phenomenon of every rainy season in Lagos, Niger, Imo, Katsina, Maiduguri, Aba, Warri, Benin, Ibadan and a constant occurrence in towns located on flat or a low lying terrain especially where little or no provision has been made for surface drainage, or existing drainage has been blocked (Ikusemoran, Kolawole \& Adegoke, 2014; Emeribeole, 2015; Umar \& Muazu, 2017).

In Jigawa State, River Hadejia, which splits into three channels in the Hadejia Nguru Wetland; the Marma channel which flows into the Nguru Lake, the old Hadejia River which joins up with the Jama'are River and the relatively small Burum Gana River, have been known for over flowing seasonally. Rainfall, combined with other environmental factors influences flood (Goes, 2001). In the 2018 rainy season, about thirty (30) people died following a flood, wind and rain storms that ravaged several Local Government Areas (LGAs) within the River basin and destroyed over sixty eight thousand $(68,000)$ hectares of farmlands (Sani, 2016; Aliyu, 2018). About 421 communities across, Jahun, Miga, Auyo, Kafin Hausa, Guri and Hadejia LGAs were reported to be more severely affected. Though government provide relief material for flood victims but was very minimal. Worse still floods have been confirmed to continuously cause huge socio-economic and environmental losses (Sani, 2016; Aliyu 2018). The 2019 rainy season also increased the footprint of flood damages especially in Auyo and Miga LGAs. Following the location of large parts of the two neighbouring LGAs, lying on the northern bank of Hadejia River (a seasonal tributary of the Komadugu Yobe, which flows into Lake Chad), many communities are placed at risk of seasonal flood.

Studies like that of Yahaya, Ahmad and Abdalla (2010) revealed that, the highest contributors to risk vulnerability in the Hadejia-Jama'are River basin of Jigawa State were found to be annual rainfall, the drainage network of the river basin and the basin slope. Also, Odunola and Balogun (2015) pointed out that, causes of flood in the Riverside along Apete community of Ibadan, were attributed to heavy rainfall, change in river course, dumping of waste in water bodies, poor drainage system, dam failure and narrow bridges. In another study, Umar and Mu'azu (2017) discovered that, the major causative factors of flood in Hayin-Gada, Dutsin-Ma of Katsina State were intense rainfall, topography, lack of dam embankment and regulatory outlets as well as overflow of stream and dam burst. In a nutshell, several other researches (like those of: Adejuwon \& Aina 2014; Emeribeole, 2015; Umar, Sulaiman, Giwa \& Sulaiman, 2018) aimed at studying flood, have reached ultimate consensus that, Nigerian river basins are conducive for human habitation, hence are more populated than the surrounding uplands. Unfortunately, they are all subjected to variety of hydro-meteorological hazards, with floods being identified as the worst. This study assesses flood risk factors in the vulnerable communities of Auyo and Miga LGAs, Jigawa State of Nigeria. 


\section{STUDY AREA}

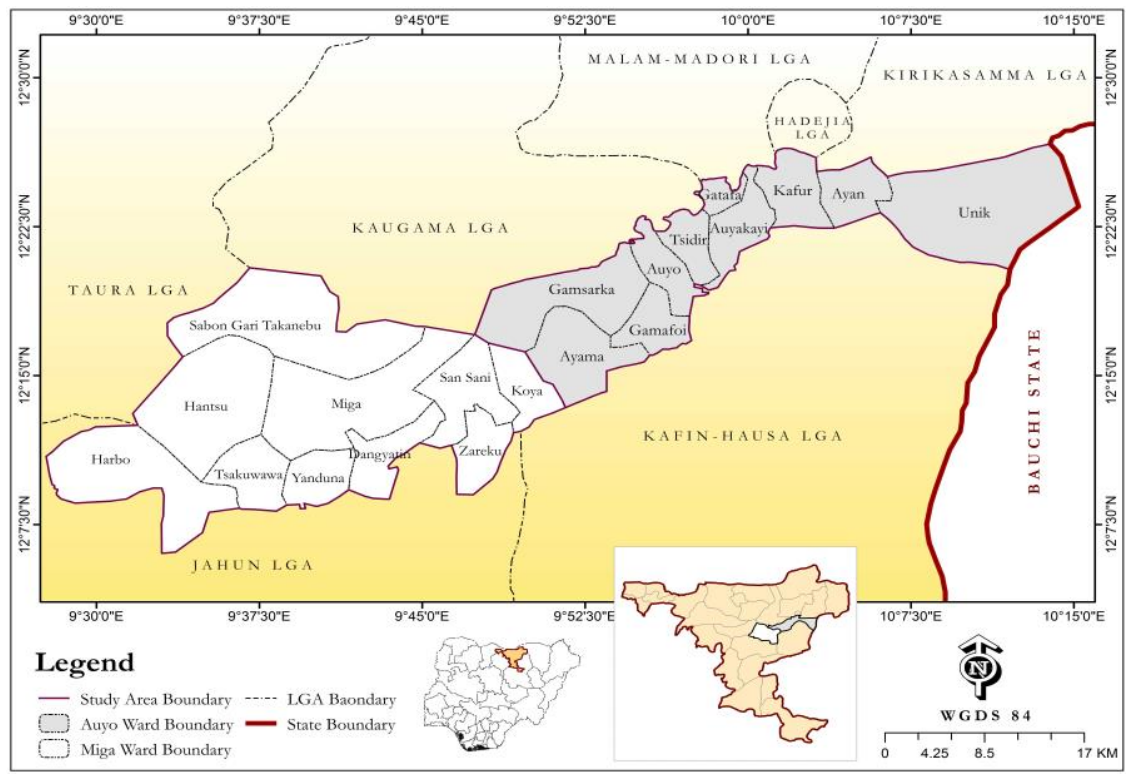

Fig. 1: The Study Area

Source: Adapted from Administrative and Topographic Maps

Auyo and Miga are two of the twenty-seven LGAs of Jigawa State. The former has an area of $512 \mathrm{~km}^{2}$, whereas the latter occupies $586 \mathrm{~km}^{2}$ (*Abubakar, Kutama \& Sulaiman, 2016 ;) The area lies between Latitudes $12^{\circ} 21^{\prime} 6.457^{\prime \prime} \mathrm{N}$ to $12^{\circ} 6^{\prime} 7.808^{\prime \prime} \mathrm{N}$ and Longitudes $9^{\circ} 28^{\prime} 0.944^{\prime \prime} \mathrm{E}$ to $10^{\circ} 15^{\prime} 28.924^{\prime \prime} \mathrm{E}$. It is bounded by Bauchi State in the east, Kafin-Hausa and Jahun LGAs in the south. In the northeast by Hadejia, Malam-Madori and Kirikasamma LGAs, in the north it is bounded by Kaugama LGA. In the northwest it is bounded by Taura and some part of Jahun LGA respectively (Fig. 1). The climate of the area is semi-arid. However, the microclimate is modified by the local effect of the Hadejia River system. The mean annual temperature is about $25^{\circ} \mathrm{C}$. The total annual rainfall ranges from $600 \mathrm{~mm}$ to $762 \mathrm{~mm}$ (Kaugama \& Ahmed, 2014). The study area is part of an extensive downstream of floodplain created by the Hadejia River. It comprises of permanent lakes and seasonally flooded pools connected by a network of channels (Abubakar et al., 2016). The LGAS have a total population figure of 260,692 . This figure is projected using equation 2 (NPC, 2009), to about 371,684 as at the year 2020 .

\section{MATERIALS AND METHOD}

Data used in this study are sourced via primary source only. It involved the use of questionnaire designed for the residents of Auyo and Miga LGAs. The vulnerable nature of the LGAs to flood, facilitated the choice of the locations under study. Judgmental (nonprobability) sampling technique also known as authoritative or purposive, is used to select the study wards. Thus, out of the 20 wards when put together, six (6), with three (3) from each LGA are chosen only on the basis of the researcher's knowledge of those areas being predominantly within river basin and experiencing flood of greater magnitude seasonally. These wards were: Harbo, Miga and San-sani within Miga LGA as well as Ayama, Auyo and Kafur of Auyo LGA respectively. Ken (2004) formula is used (equation 1) to obtain a sample size of approximately 666. Additionally, population of the selected wards was extracted from the 1991 census figure of Auyo and Miga, and was projected to 2020 using equation 2. Equation 3 is used to determine the proportion of respondents to be sampled, by adopting Yamane (1976) formula. Households were selected at random and administered questionnaire after given a brief explanation of the study. At least, two trained research 
assistants were recruited from each ward to aid the survey. Only six hundred and one (601) fully completed questionnaires retrieved were studied. Descriptive statistics and relative importance index (RII) were used for analysis. The higher the value of RII, the more important was the variable. The RII is expressed as: RII $=\Sigma \mathrm{W} /(\mathrm{A} \times \mathrm{N})$

Where, $\mathrm{W}=$ the weight given to each factor by the respondents (from 1 to 5 )

$\mathrm{A}=$ the highest weight (i.e. 5 in this case), $\mathrm{N}=$ the total number of respondents

$$
\mathrm{N}=\frac{\left[\mathrm{z}^{2} \mathrm{xp}(1-p)\right]}{1+\left[\frac{\mathrm{z}^{2} \times p(1+p)}{\mathrm{e}^{2}}\right.}
$$

Where: $N=$ sample size, $n=$ population size, $e=$ error margin (set at $5 \%=0.05$ )

$p=$ standard deviation (set at $50 \%=0.5$ ), $z=$ confidence level (set at $99 \%=2.58$ )

$\mathrm{Po}=\mathrm{P} 1(1+\mathrm{r}) \mathrm{n}$ 2

Where $\mathrm{Po}=$ projected population, $\mathrm{P} 1=$ Initial population, $\mathrm{r}=$ Growth rate $=3 \%=0.03$

$\mathrm{n}=$ Number of years projected

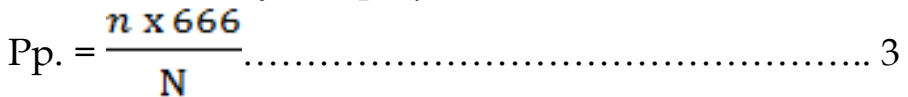

Where: $\mathrm{Pp} .=$ proportion of respondents, $\mathrm{n}=$ Population of each ward, $\mathrm{N}=$ Total population figure

\section{RESULTS AND DISCUSSION}

\section{Socio-demographic Characteristics of Respondents}

From Table 1, there were $70.72 \%$ males (which constitute the majority) and $29.28 \%$ females. The age range was 15-55 and above, with the majority (32.28\%) within 35-44 and the least $(14.64 \%)$ between 15 and 24 years. Most $(56.41 \%)$ of the respondents are married, whereas the least $(11.81 \%)$ are divorced. Secondary education accounted for the highest proportion $(32.11 \%)$ and respondents with no education constituted the lowest $(13.48 \%)$. Also, most of the respondents engage in farming $(38.27 \%)$, and trading $(31.61 \%)$, while the least were selfemployed (10.32\%). Additionally, respondents who had lived for six 6-10 years accounted for the majority $(51.58 \%)$, while those for 21 years and above accounted for the minority $(1.66 \%)$. Studies have found out that, female respondents tend to perceive risk more acutely than their male counterparts and thus, may represent a specific target audience for risk reduction strategies (Ho, Shaw, Lin \& Chiu, 2008; Lindell \& Hwang, 2008). Studies have also demonstrated that, gender and age are known to influence human vulnerability to natural hazards, more especially floods (Ashley \& Ashley, 2008; FitzGerald, Du, Jamal, Clark \& Hou, 2010). Therefore, being in their middle and active age brackets, majority of the respondents might have exhibit overall tendency towards certain physical, psychological, social and economic conditions which may in turn maximize their ability to overcome floods hazards. 
Table 1: Respondents' Socio-demographic Characteristics

\begin{tabular}{llllll}
\hline Gender & F & $\mathbf{\%}$ & Marital Status & F & \% \\
\hline Male & 425 & 70.72 & Single & 109 & 18.14 \\
Female & 176 & 29.28 & Married & 339 & 56.41 \\
Total & $\mathbf{6 0 1}$ & $\mathbf{1 0 0}$ & Divorced & 71 & 11.81 \\
Age & & & Widowed & 82 & 13.64 \\
$15-24$ & 93 & 15.47 & Total & $\mathbf{6 0 1}$ & $\mathbf{1 0 0}$ \\
$25-34$ & 110 & 18.30 & Occupation & & \\
$35-44$ & 194 & 32.28 & Farming & 230 & 38.27 \\
$45-54$ & 116 & 19.30 & Trading & 190 & 31.61 \\
55 and above & 88 & 14.64 & Civil Service & 119 & 19.80 \\
Total & $\mathbf{6 0 1}$ & $\mathbf{1 0 0}$ & Self Employed & 62 & 10.32 \\
Educational Qualification & & & Total & $\mathbf{6 0 1}$ & $\mathbf{1 0 0}$ \\
Primary & 94 & 15.64 & Period of Stay in Residence & 201 & 33.44 \\
Secondary & 193 & 32.11 & 0-5 years & 310 & 51.58 \\
Tertiary & 140 & 23.29 & 6-10 years & 57 & 9.48 \\
Informal Education & 93 & 15.47 & $11-15$ years & 23 & 3.83 \\
No education & 81 & 13.48 & $16-20$ years & 10 & 1.66 \\
Total & $\mathbf{6 0 1}$ & $\mathbf{1 0 0}$ & 21 years and above & $\mathbf{6 0 1}$ & $\mathbf{1 0 0}$ \\
\hline
\end{tabular}

Source: Field Survey, 2021

According to United Nations Development Programme-UNDP (2010), the efficiency of any initiatives targeted at reducing flood impacts, especially the efficacy of flood warning systems, strictly depends on the level of knowledge of the inhabitants and the users of inundation areas regarding local flood hazards, and the awareness of defined appropriate behavioral patterns prior to and during floods. Since, majority of the respondents have acquired one form of formal education or the other, they would perhaps exhibit positive attitudes and motivation towards flood warning systems, and disaster preparedness measures. Livelihood resilience in the face of recurring floods is also found to correlate with exposure to flood risk in various studies (Akuro et al., 2013; Abubakar et al., 2016; Umar et al., 2019). Thus, access and use of livelihood resources such as size of farmlands, availability of farm, oxen, credit as well as stability to draw help from social networks are the most important factors that determine the resilience of households to flood. Hence the dominant farming activities as a livelihood option in the study area, may have a profound impact on how the study subjects perceive risks and the livelihood resilience of the general communities to flood preparedness. Result also indicates that respondents had lived in the area for a period which is sufficient enough to enable them supply relevant information regarding floods.

\section{Prevalence of Flood Hazard}

Figure 2 indicates the number of times respondents have experienced floods over the study period (2012-2018). 


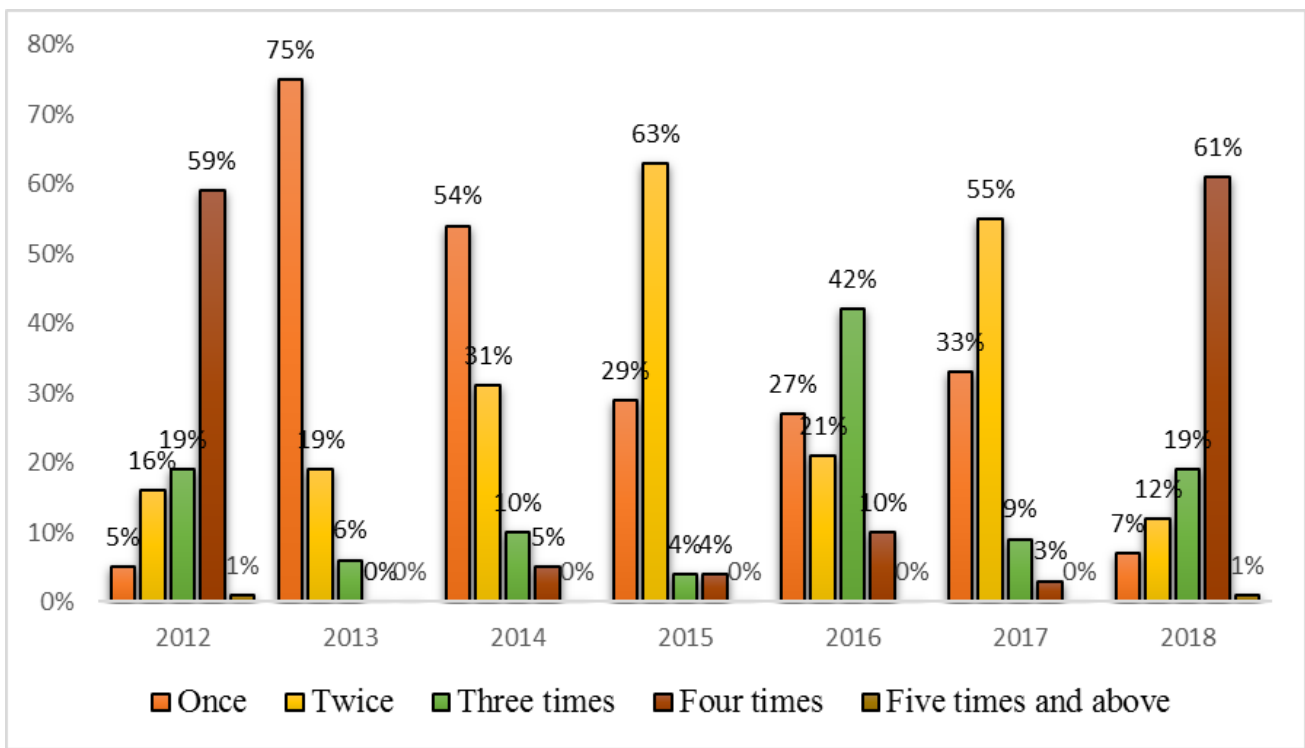

Fig. 2: Prevalence of Flood based on Respondents' Experience

Source: Field Survey, 2021

From this Figure, majority of the respondents had experienced flood once in the year 2013 and 2014, as well as twice in 2015 and 2017 as attested by 75\%, 54\%, 63\% and 55\% respectively. Most (42\%) of the respondents also claimed to witness floods three times in 2016. However, the greatest percentages which accounted for $59 \%$ and $61 \%$ have experienced flooding four times in 2012 and 2018 respectively. From the result of the analysis, flood in the study area was on the increase but, the year 2012 and 2018 had gained more responses in terms of flood size and magnitude. The increase in flood events according to Kundzewicz (2016) is a global discuss. Since global warming leads to increased storm activity, and has the potential to increase both the frequency and severity of flood and could cause a wide range of impacts. This finding is in line with Kura (2018), which revealed that, the 2012 and 2018 floods were the greatest, and had evidently placed Nigeria as a highly challenged nation by disaster risk as well as limited capacity to curtail the challenges.

\section{Duration of Surface Flood Water Stay}

Table 2 presents the typical duration of floods water standing within the study area based on the experiences of the respondents

Table 2: Duration of Surface Flood Water Stay within the Study Area

\begin{tabular}{lll}
\hline Duration & Frequency & Percentage $\%$ \\
\hline $0-24$ hours & 2 & 0.33 \\
1-3 days & 43 & 7.15 \\
4-6 days & 177 & 29.45 \\
$7-10$ days & 278 & 46.26 \\
10 days and above & 101 & 16.81 \\
Total & 601 & 100. \\
\hline Source: Field Survey, 2021 & &
\end{tabular}

Source: Field Survey, 2021

From this Table, Most of the respondents (46.26\%) voted for 7-10 days as the most frequent duration of water stay after flood before it recedes, while 0-24 hours $(0.33 \%)$ attested for the least. Though, Ogboi (2013), reported that, flood water may appear to have positive impact in maintaining the fertility of soils. However, except there were reorientation on locations, design and foundation methodology in the flood prone areas, many buildings may risk 
collapse and roads submerge. Also plants are weakened sufficiently to cause weed infestation problems usually after 24 to 48 hours of flood (Ezemonye \& Chukwudi, 2014), and hence crop yield could be reduced. Additionally, flood waters contain many things that may harm health. These may include human and livestock waste; household and medical hazardous waste, Coal ash waste, which can contain carcinogenic compounds such as arsenic, chromium, and mercury; physical objects such as wood, vehicles, and debris and even wild or stray animals such as rodents and snakes. Exposure to contaminated floodwater can cause: wound infections, skin rash, gastrointestinal illness, tetanus and so on (Kellett \& Peters, 2013). The study area could be hence exposed to severe risk of flood on housing, transportation, crop production and health

\section{Factors Influencing Floods in the Study Area}

Flood may be triggered by both natural and man-made induced factors. Table 3 , shows the relative importance index (RII) ranked from extremely important to not important. The Table also shows that, heavy rains (with RII of 4.890) was ranked the first, (very important) natural factor influencing flood. Thus, excessive rain is enough to cause floods in the right conditions (ODPM, 2013). Enough rain can oversaturate the soil, causing rivers to rise, and cause storm drains to backup. Next in rank was overflow of river/stream with RII of 4.866 . Due to the extensive downstream of the floodplain a small stream and lake can easily rise quickly after rain due to higher generated runoff. Thereby perceived as a very important factor of flood experience in the study area. Rainstorm, with RII of 4.890 was ranked third. Severe weather conditions and storms are common causes of floods. Storms bring an excessive amount of rain in a very short period of time and the powerful winds can cause huge destruction. This amount of water is too much for drainage systems to handle which leads to very serious flood. The fourth ranked factor with RII of 4.805 (very important) was long period or duration of rainfall. In the study area, the soil is generally sandy (Abubakar et al., 2016), and excess water which often exceeds the soil water retention capacity usually runs into rivers and streams, overwhelming storm drains and ditches and causing a flash flood. The fifth ranked was the nature of steep side channels. The score of 4.785 RII ranked this factor also very important. Thus, flood often occurs when there is fast runoff into lakes, rivers and other reservoirs. This is often the case with rivers and other channels that feature steep sides. The least scored natural factor of flood which is also important, was Mystical beliefs, ranked ninth with RII of 3.861. The study area is culturally and religiously oriented. Flood myths may occur in communities as part of a cycle of destruction and punishment and other supernatural beliefs.

Human induced factors of flood as shown in Table 3, revealed that, deforestation with RII of 4.389 was ranked sixth, and considered very important. Given the fact that, almost all the natural vegetation within the study area have been removed due to land clearing (Ezealor 2001; Abubakar et al., 2016), there would be little to intercept rain droplets and slows surface water runoff. The seventh very important factor (lack of flood embankment) is having RII of 4.316 (Table 3). This implies that, flood embankments which were intended to increase the water-holding capacity of the main river that drains the study area, might not potentially prevent flood water from draining back into the rivers during large precipitation events. Thereby floods the adjourning settlement. Further, poor waste disposal was ranked eighth factor, and with RII of 3.915, it appeared to be important. Improper disposal of waste along roads could physically block the drainage system, influencing the flow of runoff in the channel system. On the other hand, open dumping of waste into low lands or wetlands could deteriorate the natural flood retention capabilities, leading to flood events. In another aspect, flood events could act as a transporting agent of poorly disposed waste leading to blocking of channels, siltation of rivers, spreading of different waterborne diseases. Lack of 
drainage network with RII of 3.840 (rated important) was ranked the tenth factor. Thus, effect of poor drainage results to cracking of concrete, retaining walls, fences and foundation. In addition to this issue, Table 3 also reveals that, development and infrastructure in flood-prone areas with RII of 3.733 was ranked eleventh most influential factor of flood events.

Table 3: Ranking of the Perceived Factors Influencing Floods in the Study Area

\begin{tabular}{|c|c|c|c|c|c|c|c|c|c|c|c|}
\hline & & EI & VI & I & SI & NI & TR & TS & RII & $\mathbf{R}$ & RMK \\
\hline & Perception Score & 5 & 4 & 3 & 2 & 1 & & & & & \\
\hline SN & Man-Made & & & & & & & & & & \\
\hline 1 & Deforestation & 410 & 69 & 68 & 54 & 0 & 601 & 2638 & 4.389 & 6 & VI \\
\hline 2 & Lack of drainage network & 78 & 404 & 64 & 55 & 0 & 601 & 2308 & 3.840 & 10 & I \\
\hline 3 & Lack of flood embankment & 402 & 55 & 78 & 64 & 2 & 601 & 2594 & 4.316 & 7 & VI \\
\hline 4 & $\begin{array}{l}\text { Development and } \\
\text { infrastructure in flood-prone } \\
\text { areas }\end{array}$ & 401 & 7 & 6 & 6 & 181 & 601 & 2244 & 3.733 & 11 & I \\
\hline 5 & Sand mining & 0 & 0 & 0 & 301 & 300 & 601 & 902 & 1.500 & 13 & NI \\
\hline 6 & Impermeable surfaces & 0 & 0 & 0 & 148 & 453 & 601 & 749 & 1.246 & 14 & NI \\
\hline 7 & Climate change & 0 & 0 & 0 & 513 & 88 & 601 & 1114 & 1.853 & 12 & NI \\
\hline 8 & $\begin{array}{l}\text { Poor waste disposal } \\
\text { Natural }\end{array}$ & 99 & 398 & 58 & 46 & 0 & 601 & 2353 & 3.915 & 8 & I \\
\hline 9 & Long period of rain & 512 & 69 & 12 & 8 & 0 & 601 & 2888 & 4.805 & 4 & VI \\
\hline 10 & Overflow of river/stream & 544 & 41 & 9 & 7 & 0 & 601 & 2925 & 4.866 & 2 & VI \\
\hline 11 & Mystical & 430 & 0 & 0 & 0 & 171 & 601 & 2321 & 3.861 & 9 & I \\
\hline 12 & Steep side channels & 481 & 111 & 9 & 0 & 0 & 601 & 2876 & 4.785 & 5 & VI \\
\hline 13 & Rainstorm & 501 & 100 & 0 & 0 & 0 & 601 & 2905 & 4.833 & 3 & VI \\
\hline 14 & Heavy rains & 535 & 66 & 0 & 0 & 0 & 601 & 2939 & 4.890 & 1 & VI \\
\hline
\end{tabular}

Source: Field Survey, 2021

Key: EI=Extremely Important, VI=Very Important, SI=Slightly Important, NI=Not Important, TR=Total Response, $T S=$ Total Score, $R I I=$ Relative Importance Index, $R=$ Rank, $R M K=$ Remark

However, due to an increased level of human-produced greenhouse gases in the atmosphere, the world's climate is changing and getting warmer. Climate change was ranked the twelfth leading cause of flood in the study area. Due to low level of education (Table 1), most of the inhabitants, had little to comprehend with regard to climate change and flood nexus. With RII of 1.853, climate change was rated not important (Table 3 ). Likewise, sand mining ranked thirteenth and impermeable surfaces ranked the least (fourteenth) were disregarded by majority of the respondent with RII of 1.500 and 1.246 respectively. However, floods in the study area was naturally caused, and influenced by some human induced factors. These findings is in conformity with *Yahaya and Abdalla (2010), the study revealed that, the highest contributors to flood risk in Hadejia-Jama'are river basin were found to be annual rainfall, the drainage network in the river basin and the steep sided channel of the basin's slope.

\section{CONCLUSION AND RECOMMENDATIONS}

Effort was made to assess factors influencing flood hazard in the vulnerable communities of Auyo and Miga LGAs, Jigawa State of Nigeria. Flood in the study area was on the increase, and the worst scenario was recorded in 2012 and 2018 respectively. While factors, such as: heavy rains, rainstorm, overflow of river/stream and long period of rainfall cannot be controlled, the issue of deforestation, lack of flood embankment, poor waste disposal and drainage network, development and infrastructure in flood-prone areas may continue to prevail and damages, attributed to their mystical beliefs, is henceforth inevitable. This is rather true especially, when the respondents and the users of inundation areas were fairly knowledgeable and lived in the area for a long period of time to gain experience regarding 
local flood hazards. Likewise the dominant farming activities as a livelihood option in the study area, which would have a profound impact on how they perceive risks and the livelihood resilience of the general communities to flood preparedness. The negative effect of flood could be worsening by day. There is need therefore for; provision of proper embankment protection and water regulatory outlets, proper waste disposal system and adequate drainage network. Also create awareness on climate change and environmental effects associated with deforestation as well as development and infrastructure on floodprone areas.

\section{REFERENCES}

*Abubakar, M.M., Kutama, A.S., Sulaiman, I.M. and Ringim, A.S. (2016). Impact of Climate Change on the Hadejia-Nguru Wetlands: A Review. Dutse Journal of Pure and Applied Sciences 2(1) 150 - 158

Adejuwon \& Aina (2014). "Challenges of disaster vulnerability reduction in River State, Nigeria", Disaster Prevention and Management: An International Journal, 20(1), 27

Akuro, E.G., Gordon, T.A., Williams, W.P. (2013). Public Perception of Tidal Flooding Hazards on Bonny Island, Rivers State; Nigeria. Journal of Marine Science, 3(3): 91-99

Aliyu M.H., (2018). 39 Die in Jigawa Flood. In Daily Trust. Monday, October 1, 2018. Available on: https://www.dailytrust.com.ng/39-die-in-jigawa-flood.html Accessed on 20 th December, 2020

Ashley, S.T. and Ashley, W.S. (2008). Flood fatalities in the United States. Journal of Applied Meteorological Climatology. 4(7) 805-818

Ayinde O.E., Ojehomon, V.E.T., Daramola, F.S and Falaki, A.A. (2013). Evaluation of the effects of climate change on rice production in Niger State Nigeria. Ethiopian Journal of environmental studies and management. 6 (7) 763-773

Emeribeole, A.C. (2015). Managing Flood Disaster in Nigerian Cities: Issues and Strategies toward Meeting the Challenges in the Modern World- a Case Study of Owerri Metropolis Imo State, Nigeria (7587). Augustine Emeribeole (Pakistan) FIG Working Week 2015 from the Wisdom of the Ages to the Challenges of the Modern World Sofia, Bulgaria, 17-21 May 2015

Ezealor, A.U. (2001). Important Bird areas in Africa and associated islands. Report by Nigeria Conservation Foundation (NCF), Lagos, Nigeria. 675-688.

Ezemonye N.M., and Chukwudi, N.E. (2014). Flooding and Household Preparedness in Benin City, Nigeria. Mediterranean Journal of Social Sciences; 5(1). 532-547

Few, R., Ahern, M., Matthies F. and Kovats S. (2004). Floods, health and climate change: a strategic review. Tyndall Centre for Climate Change Research, 2004, (63).

FitzGerald, G., Du, W., Jamal, A., Clark, M. and Hou, X.Y. (2010). Flood fatalities in contemporary Australia (1997-2008). Emergency Medicine Australasia. (22) 180-186,

Goes, B. J. M. (2001). Effects of damming the Hadejia River in semiarid Northern Nigeria lessons learnt for future Management. Regional Management of Water Resources (Proceedings of a symposium held during the Sixth IAHS Scientific Assembly at Maastricht, The Netherlands, July 2001. IAHS Publ. no. 268:73-153

Ho, M.C., Shaw D., Lin S., Chiu Y.C. (2008). How do disaster characteristics influence risk perception? Risk Analysis International. Journal; 28:635-643

Ikusemoran M., Kolawole, M. S. and Adegoke K.M. (2014). Terrain Analysis for Flood Disaster Vulnerability Assessment: A Case Study of Niger State, Nigeria, American Journal of Geographic Information System. 3(3), 122-134

Kaugama, H.H., and Ahmed, B.A. (2014). Prospect and Challenges of Farming along the Hadejia-Nguru Wetland in Jigawa State, Nigeria. International Journal of Academic Research in Economics and Management Sciences, 3(6) 43. 
Kellett, J. and Peters, K. (2013). Dare to prepare: taking risk seriously. Overseas Development Institute. Also available on http://www.odi.org.uk/publications/7955 dare-preparetaking-risk-seriously. Retrieved 27th December, 2020

Ken, B. (2004), Business Statistics for Contemporary Decision Making. (Fourth Eds.) Wiley, India. ISBN 9788126508099

Kundzewicz, Z.W. (2016). Changes in Flood Risk in Europe. (1 ${ }^{\text {st }}$ Ed.). CRC Press. https://doi.org/10.1201/b12348. Wallingford, Oxfordshire, UK, pp. $516+$ xvi

Kura, A.N. (2018). Households' perceived risk and responses in Flood and Multi-hazard environment. Risk Analysis International. Journal; 28:539-556.

Lindell, M.K. and Hwang, S.N. (2008). Households' perceived personal risk and responses in a multihazard environment. Risk Analysis International. Journal; 28:539-556

NPC, (2009). "Nigeria national population census report, 2006. Retrieved from: Nigeria Population Commission (NPC) Office, Jigawa state

ODPM, (2013). Hazards. Office of Disaster Preparedness and Management. Available online at http:/ / www.odpm.gov.tt/node/15. Retrieved August 09, 2020

Odunola, O.O. and Balogun, F.A. (2015). Analyzing Household Preparedness on Flood Management in Riverside: A Focus on Apete Community in Ibadan, Nigeria. IOSR Journal of Humanities and Social Science (IOSR-JHSS) 20(7) 07-32

Ogboi, K. C. (2013). “Disaster Risk Management and Adaptation strategies Challenges and Opportunities for Physical Planning Education and practice in Nigeria". Presented at the 15th edition of MCPDP by NITP and TOPREC in Ta'al Conference hotel Lafia Nasarawa State Nigeria

Sani, Y. (2016). Flood Kills 18, Destroys 6,637 Houses in Jigawa. In Punch Newspapers. Available on: https://punchng.com/flood-kills-18-destroys-6637-houses-jigawa/ Accessed on $10^{\text {th }}$ December, 2020

Umar, N.K. and Mu'azu, A. (2017). Community Perception and Adaptation Strategies toward Flood Hazard in Hayin-gada, Dutsin-Ma Local Government Area, Katsina State, Nigeria. Dutse Journal of Pure and Applied Sciences (DUJOPAS) 3(1) 444-457

Umar, N.K., Sulaiman, A.M., Giwa, S.M. and Sulaiman, A.Y. (2018). Spatio-Temporal Analysis of Urban Expansion in Katsina Local Government Area, Katsina State, Nigeria. Sokoto Journal of Social Sciences. 8(2) 95-106

Umar, N.K., Usman, A.K., Dakata, F. and Dabo, Y. (2019). Mapping Land Use-land Cover Change Detection and Prediction in Zaria Urban Area, Kaduna State, Nigeria. Savana Journal of Environmental and Social Science, Ahmadu Bello Uniersity, Zaria Nigeria. 25(1) 92100

UNDP, (2010). Gender, Climate Change and Community-based Adaptation (United Nations Development Programme) UNDP, New York (2010)

UNISDR, (2015). "Hyogo Framework for Action 2015-2030: Building the Resilience of Nations and Communities to Disasters". United Nations International Strategy for Disaster Reduction World Conference on Disaster Reduction. Sendai Framework, Japan Reduction Education Pp.16-32

Yahaya, S., Ahmad, N. and Abdalla, R. F. (2010). Multi-criteria Analysis for Flood Vulnerable Areas in Hadejia-Jama'are River Basin, Nigeria. European Journal of Scientific Research, 42 (1) 71-83

Yamane, T. (1976). Statistics: An Introductory Analysis (2nded.). New York, Harper and Row. 